\title{
GEOMETRIC ANALYSIS AND SCOPE OF NANOFLUID IN MICRO CHANNEL HEAT SINKS FOR ELECTRONIC COOLING APPLICATION - A REVIEW
}

\author{
K. R. AGLAWE ${ }^{1 *}$, R. K. YADAV ${ }^{2}$ \& S. B. THOOL ${ }^{3}$ \\ ${ }^{I}$ Research Scholar, Department of Mechanical Engineering, National Institute of Technology, Raipur, India. \\ ${ }^{2}$ Associate Professor, Department of Mechanical Engineering, National Institute of Technology, Raipur, India. \\ ${ }^{3}$ Associate Professor, Department of Mechanical Engineering, D. J. Sanghvi College of Engineering, Mumbai, India
}

\begin{abstract}
With a technological advancement and electronic devices miniaturization, use of liquid coolants increasing continuously into the servers, laptops, and computers. Expanding the efficiency of the system is one of the technique by which sustainability of energy might be guaranteed, for which miniaturization has effectively given arrangements. Micro channel heat sinks (MCHS) are extensively utilized for enhancement of the cooling rate. MCHS seems a trustworthy cooling technology because of its higher control on heat conveying ability. A smaller size of micro channels and capacity of dispersing heat made finest decision for electronic cooling systems. The proposed examination gives a comprehensive review of available studies regarding the various parameters like geometry, pattern, manifold and nanofluid for MCHS which are helpful for cooling enhancement of the system. Also the effects of above mentioned parameters on the performance of MCHS were analyzed. The primary objective behind the study is covering a research gap into the review of various parameters effect upon a performance of MCHS. From this review, execution of micro-channel into electronic devices is greatly suggested because of its capability of protection and extension in an electronic devices lifespan.

KEYWORDS: Micro-Channels, Cooling Techniques, Heat Sink, Pattern, Nanofluid, Heat Transfer
\end{abstract}

Received: Jun 08, 2020; Accepted: Jun 28, 2020; Published: Sep 12, 2020; Paper Id.: IJMPERDJUN20201186

\section{INTRODUCTION}

One of significant worries of a $21^{\text {st }}$ century is a protection of energy and the journey of advancement for optional energy sources. Conventional resources of energy, being persistently misused, are relied upon to getting depleted into an upcoming decade (Omer 2008). Researchers, specialists and mechanical associations are unendingly flourishing to address this essential concern with the goal of innovative product accomplishments (Waghmare et al. 2020). Technological advancement early in the 1960s caused it conceivable for mounting incorporated to accumulate circuits upon the silicon chip. After 1968s, microchips sizes have decreased by 100 to 1 micrometer and a quantity of sections into the chips have expanded by 1 to $10^{5}$ (Kakaç et al. 2012). In ongoing decades, broad improvements have been accomplished into the micropumps, micro fuel cells (Islam et al. 2004), micro heat exchangers, micro bio-chips (Kakac 2012) and micro channel for cooling of a solar system (Di Capua et al. 2018). On the other hand, a fundamental issue into decreasing a chip sizes is an expansion into a delivered heat (Tullius et al. 2011).

The authors, (Tuckerman 1981) primarily clarified an idea of micro channel heat sinks (MCHS) and anticipated that single-phase cooling into micro channels might expel heat around the rate $10 \times 10^{6} \mathrm{~W} / \mathrm{m}^{2}$. Forced 
convection and fluid injection in channels have been utilized for quicker and bigger scope of cooling into the industries for quite a long time. Micro channel transfer of heat has famous and intriguing due to higher coefficients of heat transfer and lower to medium pressure drops compared to other cooling systems (Phillips 1988). For instance, MCHS have been exhibited for higher power laser diode cluster at heat flux evacuation rate upto $5 \times 10^{6} \mathrm{~W} / \mathrm{m}^{2}$ (Beach et al. 1992).

When a necessity of cooling is more than $1 \times 10^{6} \mathrm{~W} / \mathrm{m}^{2}$, a cooling unable to be effectively met either by basic air/water cooled systems. Within numerous applications, wherever higher heat flux of devices must be scattered, a necessary heat sinks should be bigger than a devices themselves (Mundinger et al. 1988). The heat flux and temperature of the electronic device below $348.15 \mathrm{~K}$ is desirable for optimal device functioning (Taylor and Solbrekken 2008). Heat losses in the range of $6 \times 10^{6}-10 \times 10^{6} \mathrm{~W} / \mathrm{m}^{2}$ is the latest challenge of a current decade. However, the heat flux of numerous superior electronic devices is currently a lot high than predictions (Murshed and Castro 2017; Waghmare et al. 2020; Mahmoud et al. 2013). Air is (Kleiner et al. 1995) utilized a type of coolant as per accessibility and stability into traditional cooling, like fins and fan, unable to expel in excess of $10^{6} \mathrm{~W} / \mathrm{m}^{2}$ from electronic devices because of low coefficient of heat transfer (Dix et al. 2008). As survey carried out at various electronics shop in central and western India, atmospheric temperature in summer season approaches around $321 \mathrm{~K}$. At that working condition, heat flux and temperature of electronic devices reached upto 375-385 K. This higher temperature is very much harmful for the working device which may further causes damage to the internal parts. As several researchers suggested a utilization of MCHS having a liquid as a coolant medium, particularly water due to higher capacity of heat transfer and simpler availability (Arani et al. 2017). The greater surface-volume proportion and higher decrease into thickness of the thermal boundary layer can prompt the decrease into the thermal resistance (Baru et al., 2015; Mohamad Noh and Che Sidik 2014). Various examinations have been done previously for the optimized performance. By altering the different factors like reducing hydraulic diameter, superior heat elimination would be accomplished by an expansion into a quantity of channels and accessible surface of heat transfer into a similar space. Altering the various geometry of different parameters like shape of cross section, manifold, pattern, and nanofluid would result in optimization of various dependent parameters. Besides, in a MCHS, consideration of various factors like thermal-hydraulic performance, capability of fabrication, reliability, compatibility, and mostly commercialization is essential.

In current work, a quality research articles are reviewed and the impact of alteration into various geometric variables upon pressure drop and performance of heat transfer for MCHS as far as shape, pattern, and manifolds are concerned. The fundamental explanations behind is to provide all aspects of geometry variables and a background to researchers who need to begin investigating in current area. At the end, reviews have been carried out on some of the commercialized models, which prove that the vast majority of results from scientifically investigation are applied to commercialized ones. In any case, development and cost are two fundamental variables which ought to be thought of.

\section{VARIOUS MANUFACTURING TECHNIQUES AND EFFECTIVE PARAMETERS FOR COOLING ENHANCEMENT IN MCHS}

Another key concern seems to be the microchannel manufacturing of a desired shape and size on a required material. Studies used various manufacturing techniques of microchannel fabrication. Figure 1 shows the various manufacturing techniques used for MCHS. 


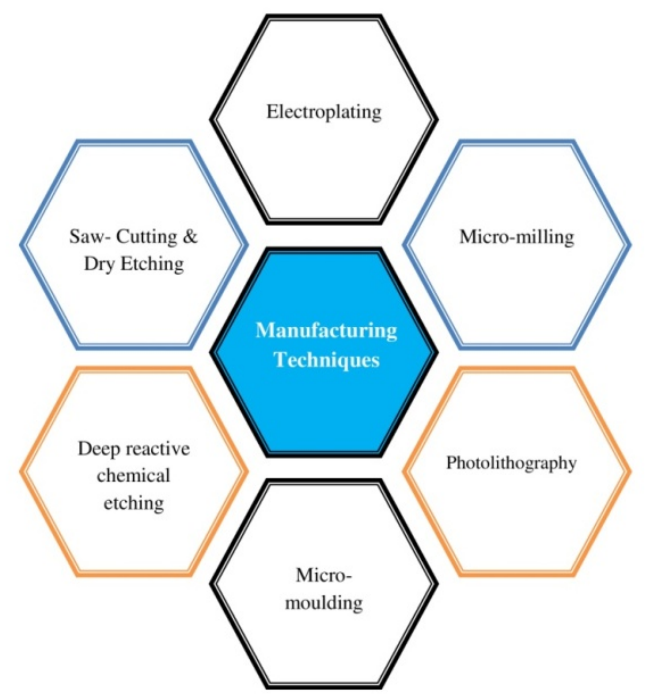

Figure 1: Manufacturing techniques for MCHS

Table 1 shows some of the popular manufacturing techniques and the form of micro - channels that was created. Kandlikar and Grande revealed that microchannels manufacturing technology had evolved rapidly by miniaturization of conventional machines technologies to a implementation of recent methodologies used for the manufacturing of semiconductors. Such technologies modified the micro - channel heat sink field scenario, many number of reputed industries have approaches in dealing associated with microchannels.

Table 1: Typical manufacturing techniques of microchannel

\begin{tabular}{|c|c|c|c|l|}
\hline Author & $\begin{array}{c}\text { Shape of } \\
\text { MCHS }\end{array}$ & Material & Dimensions $(\mathbf{H}, \mathbf{W}) \mathbf{m m}$ & Manufacturing Techniques \\
\hline $\begin{array}{c}\text { (Papautsky et } \\
\text { al. 1998) }\end{array}$ & Rectangular & Glass and $\mathrm{Si}$ & $\mathrm{H}=50$ to $100, \mathrm{~W}=300$ to 1500 & Electroplating \\
\hline $\begin{array}{c}\text { (Lee et al., } \\
\text { 2005) }\end{array}$ & Rectangular & $\mathrm{Cu}$ & $\mathrm{H}=5 * \mathrm{~W}, \mathrm{~W}=194$ to 534, & Micro-milling \\
\hline $\begin{array}{c}\text { (Wu et al., } \\
\text { 2005) }\end{array}$ & Trapezoidal & $\mathrm{Si}$ & $\mathrm{H}=56.5, \mathrm{~W}_{1}=251, \mathrm{~W}_{2}=155.7$ & Photolithography method \\
\hline $\begin{array}{c}\text { (Mei et al. } \\
2008)\end{array}$ & Rectangular & $\mathrm{Cu}$ and $\mathrm{Al}$ & $\mathrm{H}=400, \mathrm{~W}=137$ to 174 & Micro-moulding \\
\hline $\begin{array}{c}\text { (Wu et al. 2010) } \\
\text { (Chen and } \\
\text { Garimella 2011) }\end{array}$ & Rectangular & $\mathrm{Si}$ & $\mathrm{H}=50, \mathrm{~W}=483.4$ & $\begin{array}{l}\text { Deep reactive chemical } \\
\text { etching }\end{array}$ \\
\hline $\begin{array}{c}\text { (Lee et al. } \\
2011)\end{array}$ & Rectangular & $\mathrm{Si}$ & $\mathrm{H}=389, \mathrm{~W}=100$ & Saw- Cutting \\
\hline
\end{tabular}

The efficient factors considering rate of cooling are microchannel geometry, working fluid, irregularity, and inlet/outlet circumstances (Hussien et al., 2016). The appropriate choice of these factors mentioned is a major element in the removal of the heat generated (Almoli et al. 2012).

\subsection{Various Geometries of MCHS}

Various geometries of microchannel, such as rectangular, triangular, trapezoidal, diamond, circular, and sometimes hexagonal forms, were used into the effort for improvement in all thermal performance (Perret et al., 1998). The different geometries of the microchannel such as (a) rectangular, (b) trapezoidal, (c) triangular, (d) circular, (e) hexagonal, \& (f) 
diamond are as shown in figure 2

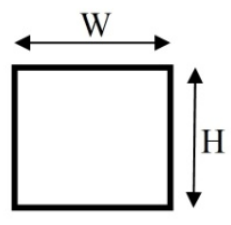

$\mathrm{W}$

(a)

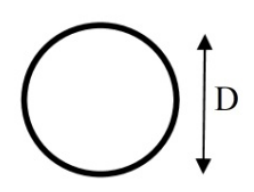

(d)

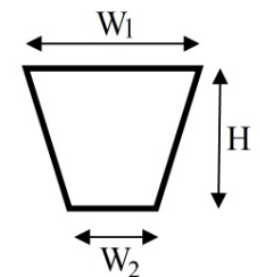

(b)

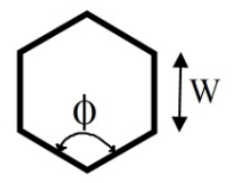

(e)

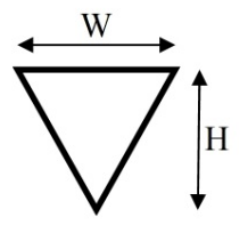

(c)

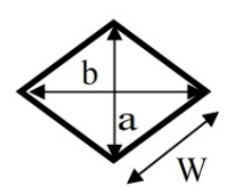

(f)

Figure 2: Various microchannel geometries

The prime reason of the use of various geometries by researcher was a need to increase the efficient heat transfer area allowed and minimize convective thermal resistance. Lowering total thermal resistance is among the most major aspects of most research. In order to increase surface area, heat transfer augmenters like cavities (Chai et al. 2013) and ribs (Husain and Kim 2009) were utilized. The augmenters results in negligible thermal efficiency gains or lowering thermal resistance. These improvements however comes at cost of high pumping power demands (Mohammed et al., 2011b). The microchannel dimensions ranged between $10 \mathrm{~mm}$ and $1500 \mathrm{~mm}$. Most often, the large number of studies employing rectangular microchannel heat sinks demonstrated that this was the best option according to scientists. This was probably due to its ease of machining, it's own stability (Hetsroni et al. 2005) as well as its exceptionally high thermal performance (Perret et al., 1998).

\subsection{Various Patterns of MCHS}

In recent years, examination of various flowing path patterns as into the heat sinks had drawn considerable attention. A heat sink's performance could improved through adjusting channel pattern to irregular geometries, wherein supplementary flows or mixing of liquid are being created, often followed through charge of a pressure drop. Hence, achieving the equilibrium among pressure drop penalties and heat transfer performance is indeed the extremely important for obtaining an appropriate pattern. Above condition implies that certain situations lead heat transfer to increase whereas pressure drop to reduce. So researchers need to explain the items are relevant in the design (Rakhsha et al. 2015). Patterns are broadly divided into the four types as shown in Figure 3 


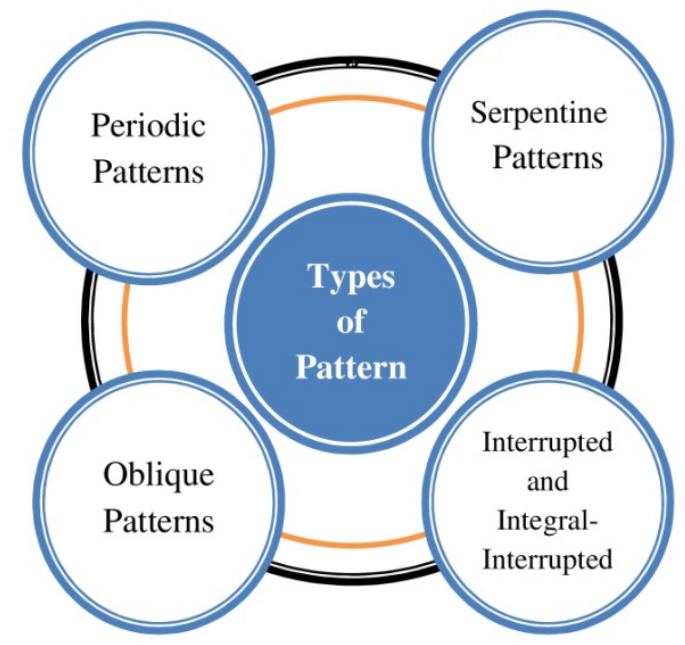

Figure 3: Various types of Patterns in MCHS

\subsection{Various Structures and Headers of manifolds in MCHS}

While considering the distribution of flow, structures of manifold can be separated as below,

(i) Consecutive type manifold and (ii) Bifurcation type manifold

\subsubsection{Consecutive type manifold}

As shown in Figure 4, a consecutive manifold consisting with one primary inlet port as well as some ports branched from its primary port. Consecutive manifolds are classified into four categories depending on the configuration of the primary port and branch ports, i.e. (i) Dividing flow, (ii) Combining flow, (iii) Reverse flow (U- type) and (iv) Parallel flow (Z- configuration) (Bajura and Jones 1976; Datta and Majumdar 1983; Tomor and Kristóf 2017; J. Wang and Wang 2015).

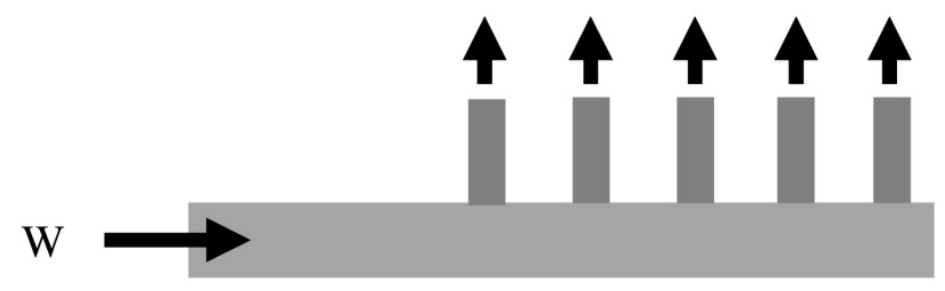

\subsubsection{Bifurcation type manifold}

Figure 4: Consecutive type manifolds

Figure 5 shows the bifurcation type manifold which is a structure as good as tree in having primary inlet and divided into several branches. An explanation for both the rise within that form of pressure drop was its presence of several branches that are reduced in length by these diameters. Bifurcation manifolds at low velocities have strong flow uniformity (P. Li, Coopamah, and Ki 2008; Liu and Li 2013). Their dynamic nature nevertheless makes them unconventional (Wang 2011). Using nanofluids as a coolant, (Bahiraei and Heshmatian 2017) utilized this manifolds for achieving optimized effectiveness into the cooling applications. One of key element of this type of manifolds is a uniformly distributing the flow into branches that could result in uniform CPU temperature. 


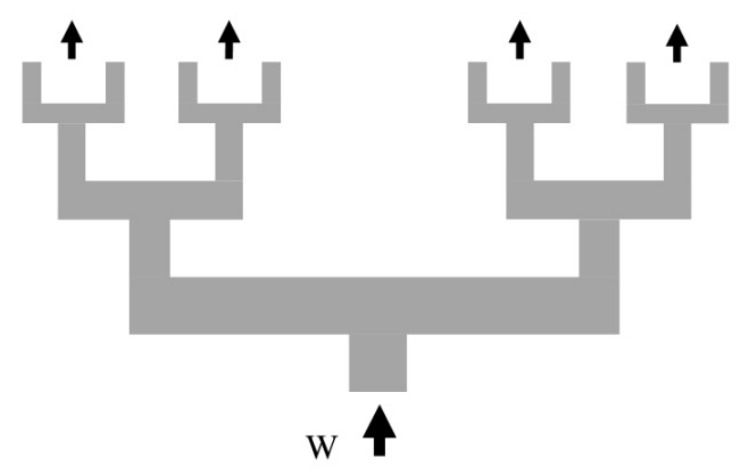

Figure 5: Bifurcation type manifolds

\subsubsection{Different shapes and architectures of Headers in MCHS}

Xia et al., studied an impact of various shapes of header (triangular/rectangular/trapezoidal) as in figure 6 (Ebrahimi et al. 2016). Deionized water was being utilized in experiment, and $2 \mathrm{M} \mathrm{Wm}^{-2}$ heat flux were transferred to a base of its sink. Experimental study revealed how geometric shape influence on a microchannel has an essential role to play into the influencing heat transfer efficiency. Compared with trapezoidal and triangular configurations, the rectangular head shape appears having greater uniformity of flow. Then the optimized microchannel shape is experimentally tested.

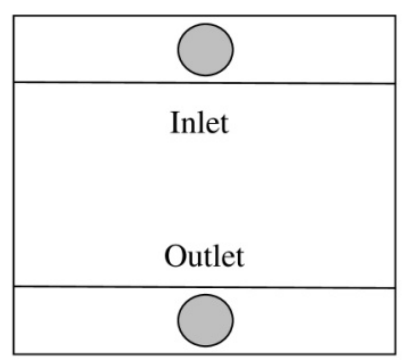

(a)

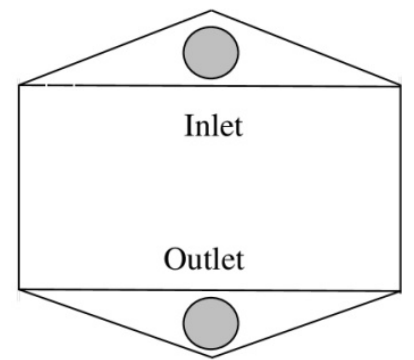

(b)

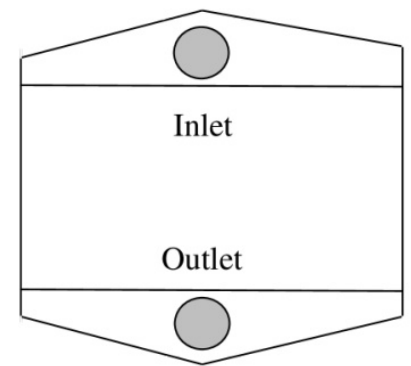

(c)

Figure 6: Various header shapes

(Manikanda Kumaran et al., 2013) investigated five positions of inlet and outlet, five rectangular outlet header inlet header shapes, and four outlet header shapes with a rectangular inlet header. To evaluate different configurations and different header types, authors utilized pressure drop and mal-distribution factor. They noticed the presence of MLD flow in the inlet header which is the outcome of the fluid recirculation and separation. 


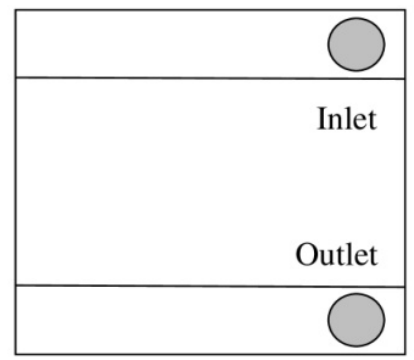

(a)

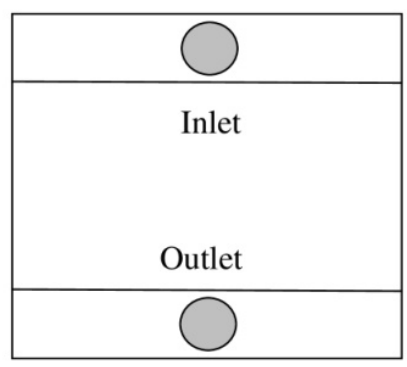

(b)

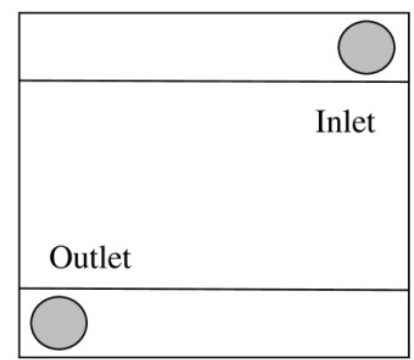

(c)

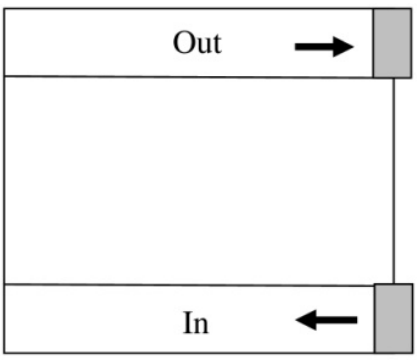

(d)

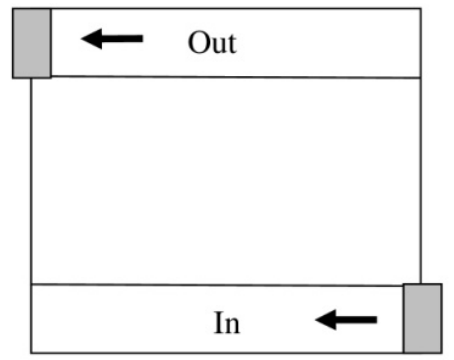

(e)

Figure 7: Various header locations

\subsection{Nanofluid for MCHS}

Nanofluids have been used as a substitute to replacing ethylene glycol or a water mixture. One or two step processing is the popular process utilized for nanofluid processing. The nanoparticle material and the base fluid are essential aspects for the creation of nanofluids. Nanofluids like oxide ceramics $\left(\mathrm{Al}_{2} \mathrm{O}_{3}\right.$ and $\mathrm{CuO}$ ), nitride ceramics ( $\mathrm{AlN}$ and $\mathrm{SiN}$ ), carbide ceramics ( $\mathrm{SiC}$ and $\mathrm{TiC}$ ), metals ( $\mathrm{Cu}, \mathrm{Ag}$, and $\mathrm{Au}$ ), carbon nanotubes, semiconductors ( $\mathrm{TiO} 2$ and $\mathrm{SiC}$ ), and composite materials have been used for various nanoparticles. This products are widely used with a liquid base like ethylene glycol, water, and oil (Ghale et al., 2015).

One of the techniques used only to manufacture nanoparticles by one-step process is the physical vapor deposition (PVD) technique or liquid chemical process. However, owing to the difficulties of removing the nanoparticles from the liquid, PVD did not earn the attention. Recent advances in nanofluid technology have led to the development of a direct evaporation device in which liquid ethylene glycol flows under low vapor pressure. Copper vapor can condense in the nanoparticles that raises ethylene glycol's thermal conductivity to 40 percent by addition of 0.3 percent of concentration of $\mathrm{Cu}$ nanoparticles. This technique can be utilized with lower pressure vapour. The other approach used into nanoparticles processing is the use of chemical synthesis. This method will give up a stable nanofluid of Copper-in-Ethylene glycol (Ahmed et al. 2016). Compared to PVD method this technique is well identified for its ease and lower price.

Another approach is the two-step processes that use nanoparticles that must first be generated and then combined with the base fluids. The process is commonly used in the development of nanofluids. The key explanation is that nanopowders are easy to get. Some of the nanoparticles in the form of dried agglomerates are used which have greater dimensions than single particles. Sedimentation approach is widely employed to assess nanofluid stability. Comparing engineered nanofluids to traditional solid-liquid suspension, engineered nanofluids have improvements into intensifying heat transfer between the particles and fluids from their high surface area, offering greater surface of heat transfer (Ebrahimi et al. 2016). In addition, main Brownian particle movement provides higher dispersal constancy and decreases pumping strength, blockage problems with particles, and simple properties adjustment to meet the requirement. Such are 
the widely recognized nanofluid benefits.

\section{EFFECT OF VARIOUS PARAMETERS ON PERFORMANCE OF MCHS}

\subsection{Effect of Geometries of MCHS}

Several of the major works are reviewed in this section where descriptions of the heat sinks are given into Table 2, and critical cases are discussed below.

Table 2: Description of the different cross section articles

\begin{tabular}{|c|c|c|c|c|c|}
\hline Reference & $\begin{array}{l}\text { Heat sink } \\
\text { dimensions } \\
(\mathrm{mm})\end{array}$ & Geometry & $\begin{array}{c}\text { Heat } \\
\text { flux/Heat }\end{array}$ & $\begin{array}{l}\text { Re/ Flow } \\
\text { rate }\end{array}$ & Outcome \\
\hline $\begin{array}{l}\text { (Gunnasegaran } \\
\text { et al. 2010) }\end{array}$ & $22 \times 12 \times 1.5$ & $\mathrm{RC}, \mathrm{TZ}, \mathrm{TR}$ & & $100-800$ & $\begin{array}{c}\text { In rectangular shape decrement in } \\
\text { liquid temperature about } 45 \text { to } 0 \\
\text { K was noted. }\end{array}$ \\
\hline $\begin{array}{l}\text { (F. Zhou and } \\
\text { Catton 2011) }\end{array}$ & $51 \times 3$ & $\begin{array}{l}\text { SQ, CR, EL, } \\
\text { NACA, Drop- } \\
\text { form }\end{array}$ & $10 \mathrm{~W}$ & & \\
\hline $\begin{array}{c}\text { (Alfaryjat et al. } \\
\text { 2014) }\end{array}$ & $22 \times 12 \times 1.5$ & $\mathrm{HX}, \mathrm{RH}, \mathrm{CR}$ & & $100-1000$ & \\
\hline $\begin{array}{c}\text { (Alfaryjat et al. } \\
\text { 2014) }\end{array}$ & $16 \times 6$ & $\mathrm{CR}, \mathrm{SQ}, \mathrm{TR}$ & $1 \mathrm{~W}$ & & \\
\hline $\begin{array}{c}\text { (Duangthongsuk } \\
\text { and Wongwises } \\
\text { 2015) }\end{array}$ & $\mathrm{Dh}=1.2$ & CR, SQ & $\begin{array}{l}20000 \text { and } \\
50000 \\
\mathrm{~W} / \mathrm{m}^{2}\end{array}$ & $700-3700$ & $\begin{array}{l}\text { Circular shape performance was } \\
6 \% \text { to } 9 \% \text { superior than the square }\end{array}$ \\
\hline $\begin{array}{l}\text { (Abdoli et al., } \\
\text { 2015) }\end{array}$ & $2.45 \times 2.45$ & $\begin{array}{c}\mathrm{CR}, \mathrm{HD}, \\
\text { modified HD, } \\
\text { and symmetric } \\
\text { convex }\end{array}$ & $\begin{array}{c}10 \times 10^{6}- \\
20 \times 10^{6} \\
W / m^{2}\end{array}$ & & $\begin{array}{l}\text { The convex pumping power was } \\
\text { less than the CR shape, HD, and } \\
\text { modified HD. }\end{array}$ \\
\hline $\begin{array}{l}\text { ( Wang et al., } \\
\text { 2016) }\end{array}$ & $10 \times 7.62 \times 44.8$ & $\mathrm{RC}, \mathrm{TZ}, \mathrm{TR}$ & $10^{6} \mathrm{~W} / \mathrm{m}^{2}$ & $100-1000$ & $\begin{array}{c}\mathrm{R}_{\mathrm{TR}} / \mathrm{R}_{\mathrm{RC}}=11.82 \% \\
\mathrm{R}_{\mathrm{TZ}} / \mathrm{R}_{\mathrm{RC}}=1.01 \%\end{array}$ \\
\hline $\begin{array}{l}\text { (Hua et al. } \\
\text { 2016) }\end{array}$ & & $\begin{array}{l}\text { CR, EL, SQ, DD, } \\
\text { TR }\end{array}$ & & $100-1000$ & $\begin{array}{l}\mathrm{Re}>600 \text { f reduced rapidly with } \\
\text { increase in Reynolds number. }\end{array}$ \\
\hline $\begin{array}{l}\text { (Zhang et al., } \\
\text { 2017) }\end{array}$ & & $\mathrm{RC}, \mathrm{TZ}, \mathrm{CR}$ & & $\begin{array}{l}0.5 \text { to } 4 \\
\mathrm{~cm}^{3} / \mathrm{s}\end{array}$ & $\begin{array}{c}\mathrm{R}_{\mathrm{cov}, \mathrm{RC}} / \mathrm{R}_{\mathrm{cov}, \mathrm{TR}}=69.5 \%, \mathrm{R}_{\mathrm{cov}, \mathrm{CR}} / \\
\mathrm{R}_{\mathrm{cov}, \mathrm{TR}}=39.5 \%\end{array}$ \\
\hline $\begin{array}{l}\text { (Yang, Jin, et al. } \\
\text { 2017) }\end{array}$ & $10.3 \times 10.3$ & $\mathrm{RH}, \mathrm{HD}$, sine & $\begin{array}{c}144 \times 10^{4} \\
\mathrm{~W} / \mathrm{m}^{2}\end{array}$ & & \\
\hline $\begin{array}{l}\text { (Yang, Wang, et } \\
\text { al. 2017) }\end{array}$ & $6 \times 0.2$ & $\begin{array}{l}\text { TR, SQ, PT, HX, } \\
\text { CR }\end{array}$ & $72 \mathrm{~W}$ & $100 \mathrm{ml} / \mathrm{min}$ & $\begin{array}{l}\text { Heat sink highest temperature was } \\
\text { for the } 326.726 \mathrm{~K} \text { for TR, } 324.752 \\
\mathrm{~K} \text { for SQ, } 325.796 \mathrm{~K} \text { for PT, } \\
\text { 324.203 K for HX, and } 326.347 \mathrm{~K} \\
\text { for CR shape of pin-fin cross- } \\
\text { section. }\end{array}$ \\
\hline $\begin{array}{l}\text { (Sakanova and } \\
\text { Tseng 2018) }\end{array}$ & & CR, Cone, HD & & $312-1562$ & $\begin{array}{l}\text { Heat transfer coefficient found } \\
\text { same after } 0.03 \mathrm{~m} / \mathrm{s} \text { of inlet } \\
\text { velocity of } \mathrm{CR} \text { and } \mathrm{HD} \text { shape. }\end{array}$ \\
\hline
\end{tabular}

Note: CR-Circular, DD-Diamond, EL-Elliptical, HD-Hydrofoil, HX-Hexagonal, PT-Pentagonal, RC-Rectangular, RH-Rhombus, SQ-Square, TR-Triangular, TZ-Trapezoidal

Several authors (Gunnasegaran et al. 2010; Wang et al., 2016) conducted numerical research into the impacts of multiple geometric parameters upon heat transfer characteristics of MCHS. In terms of heat transfer, rectangular have the 
dominance of a rectangular shape according to the results; whereas worst efficiency had found in triangular shape. (Alfaryjat et al. 2014) studied numerically the thermal hydraulic efficiency of MCHS at numerous aspect ratios which were investigated in different forms compared to other researchers. Researchers found better in temperature distribution in circular shape, and the temperature of top wall was greater than those another situations. In addition, the lowest pressure decrease and the highest heat transfer coefficient, belong to the circular and hexagonal form respectively. On the empirical analysis, (Abdoli et al., 2015) found that the circular and rectangular shapes have a highest and minimum pressure drops, respectively. Trapezoidal shapes also have lower thermal resistance to complete convection, while the rectangular form had the highest.

\subsection{Effect of Patterns of MCHS}

Lists of all papers studied are provided into the Table 3 and are discussed in depth as follows, some of them requiring further information.

Table 3: Few articles regarding patterns of MCHS

\begin{tabular}{|c|c|c|c|c|c|c|}
\hline Reference & $\begin{array}{c}\text { Heat } \\
\text { sink } \\
\text { Mate } \\
\text { rial } \\
\end{array}$ & Pattern & $\begin{array}{l}\text { Channel } \\
\text { dimension } \\
\quad s\end{array}$ & $\begin{array}{l}\text { Heat flux } \\
\text { /Power } \\
\text { input }\end{array}$ & $\begin{array}{l}\mathrm{Re} / \text { Flow } \\
\text { rate }\end{array}$ & Outcome \\
\hline $\begin{array}{l}\text { (Mohammed et } \\
\text { al., 2011b) }\end{array}$ & $\begin{array}{l}\text { Alum } \\
\text { inum }\end{array}$ & WV & $\begin{array}{c}430 \times 280 \times \\
1000 \mu \mathrm{m}\end{array}$ & $100 \mathrm{~W} / \mathrm{m}^{2}$ & $100-1000$ & $\begin{array}{l}\text { Increment in the amplitude of } \\
\text { wave not essentially increases } \\
\text { the heat sink performance. }\end{array}$ \\
\hline $\begin{array}{l}\text { (Mohammed, et } \\
\text { al., 2011a) }\end{array}$ & $\begin{array}{l}\text { Alum } \\
\text { inum }\end{array}$ & $\begin{array}{c}\mathrm{ZZ}, \mathrm{CV} \text {, and } \\
\mathrm{ST}\end{array}$ & $\begin{array}{c}430 \times 280 \times \\
1000 \mu \mathrm{m}\end{array}$ & $100 \mathrm{~W} / \mathrm{m}^{2}$ & $100-1000$ & $\begin{array}{l}\text { Dean vortices formation into } \\
\text { curvy and wavy patterns with } \\
\text { resulting secondary flows and } \\
\text { boundary layer in disturbed } \\
\text { form. }\end{array}$ \\
\hline $\begin{array}{l}\text { (M. Khoshvaght- } \\
\text { Aliabadi et al. } \\
\text { 2017) }\end{array}$ & $\begin{array}{l}\text { Alum } \\
\text { inum }\end{array}$ & $\begin{array}{l}\text { TR, TZ and } \\
\quad \text { SN }\end{array}$ & $\begin{array}{c}1 \times 1 \times 100 \\
\mathrm{~mm}\end{array}$ & & $650-3000$ & $\begin{array}{l}\text { More heat transfer effect on } \\
\text { trapezoidal heat sink } \\
\text { considered to triangular and } \\
\text { sinusoidal heat sinks. }\end{array}$ \\
\hline $\begin{array}{c}\text { (Aliabadi et al., } \\
\text { 2016) }\end{array}$ & $\begin{array}{l}\text { Alum } \\
\text { inum }\end{array}$ & $\begin{array}{c}\mathrm{ZZ} \text { with TR, } \\
\mathrm{RC} \text {, and CR } \\
\text { nooks in } \\
\text { both positive } \\
\text { and negative } \\
\text { direction }\end{array}$ & $\begin{array}{c}1 \times 1 \times 100 \\
\mathrm{~mm}\end{array}$ & & $100-900$ & $\begin{array}{l}\text { Heat transfer performance was } \\
\text { improved due to messy } \\
\text { advection and boundary layers } \\
\text { disruption. }\end{array}$ \\
\hline $\begin{array}{l}\text { (M. Khoshvaght- } \\
\text { Aliabadi et al., } \\
\text { 2017a) }\end{array}$ & $\begin{array}{l}\text { Alum } \\
\text { inum }\end{array}$ & $\begin{array}{l}\text { Plate fins } \\
\text { and plate-pin } \\
\text { fins: TR, } \\
\text { SN, and TZ }\end{array}$ & $\begin{array}{c}1 \times 1 \times 100 \\
\mathrm{~mm}\end{array}$ & $50 \mathrm{~W}$ & $100-900$ & $\begin{array}{l}\text { Lower pressure drop and } \\
\text { higher coefficient of heat } \\
\text { transfer observed in heat sinks } \\
\text { for plate-pin fins compared to } \\
\text { heat sinks for plate fins. }\end{array}$ \\
\hline $\begin{array}{l}\text { (M. Khoshvaght- } \\
\text { Aliabadi et al., } \\
\text { 2017b) }\end{array}$ & $\begin{array}{l}\text { Alum } \\
\text { inum }\end{array}$ & $\begin{array}{l}\text { Interrupted- } \\
\text { inline, } \\
\text { Integral- } \\
\text { interrupted, } \\
\text { and } \\
\text { interrupted- } \\
\text { staggered of } \\
\text { straight and } \\
\text { WV }\end{array}$ & $\begin{array}{c}1 \times 1 \times 100 \\
\mathrm{~mm}\end{array}$ & $25000 \mathrm{~W} / \mathrm{m}^{2}$ & $100-900$ & $\begin{array}{l}\text { The spread out configurations } \\
\text { outcomes considerable } \\
\text { decrease of base temperature } \\
\text { compared to inline } \\
\text { arrangements. }\end{array}$ \\
\hline (Sui et al., 2011) & $\begin{array}{c}\text { Copp } \\
\text { er }\end{array}$ & WV & $\begin{array}{l}404 \times 205 \times \\
25000 \mu \mathrm{m}\end{array}$ & $5 \times 10^{5} \mathrm{~W} / \mathrm{m}^{2}$ & $300-800$ & $\begin{array}{l}\text { An increase in the heat } \\
\text { transfer coefficient and } \\
\text { friction factor were equal to }\end{array}$ \\
\hline
\end{tabular}




\begin{tabular}{|c|c|c|c|c|c|c|}
\hline & & & & & & $\begin{array}{l}149 \% \text { and } 211 \% \text {, and } 41 \% \text { and } \\
76 \% \text {, respectively. }\end{array}$ \\
\hline $\begin{array}{l}\text { (Al-Neama et al. } \\
\text { 2017) }\end{array}$ & $\begin{array}{c}\text { Copp } \\
\text { er }\end{array}$ & $\begin{array}{c}\text { Serpentine: } \\
\text { SPM, DPM, } \\
\text { and TPM }\end{array}$ & $\begin{array}{c}2 \times 1.5 \times 25 \\
\mathrm{~mm}\end{array}$ & $100 \mathrm{~W}$ & $\begin{array}{l}0.1-1 \\
1 / \mathrm{min}\end{array}$ & $\begin{array}{l}\text { The SPM performed better } \\
\text { thermally. In DPM and TPM, } \\
\text { the pressure drop and the } \\
\text { velocity were less than in } \\
\text { SPM. }\end{array}$ \\
\hline $\begin{array}{l}\text { (Al-Neama et al. } \\
\text { 2018) }\end{array}$ & $\begin{array}{c}\text { Copp } \\
\text { er }\end{array}$ & $\begin{array}{l}\text { Serpentine: } \\
\text { SMPF, } \\
\text { SMCF }\end{array}$ & $\begin{array}{c}2 \times 1.5 \times 25 \\
\mathrm{~mm}\end{array}$ & $\begin{array}{l}6.2 \times 10^{5} \\
\mathrm{~W} / \mathrm{m}^{2}\end{array}$ & $\begin{array}{c}0.053- \\
3181 / \mathrm{min}\end{array}$ & \\
\hline (Sui et al. 2010) & $\begin{array}{l}\text { Silico } \\
\mathrm{n}\end{array}$ & WV & $150 \mu \mathrm{m}$ & $\begin{array}{l}1.5 \times 10^{6} \text { and } \\
3 \times 10^{6} \mathrm{~W} / \mathrm{m}^{2}\end{array}$ & $100-800$ & $\begin{array}{l}\text { The heat transfer enhancement } \\
\text { in the wavy microchannels } \\
\text { was much higher than the } \\
\text { pressure drop limit. }\end{array}$ \\
\hline $\begin{array}{l}\text { (L. Lin et al. } \\
\text { 2017) }\end{array}$ & $\begin{array}{l}\text { Silico } \\
\mathrm{n}\end{array}$ & $\begin{array}{l}\text { wavelength } \\
\text { of } 2000 \mu \mathrm{m} \\
\text { and } \\
\text { amplitude of } \\
30 \mu \mathrm{m}\end{array}$ & $\begin{array}{c}250 \times 80 \times 1 \\
4000 \mu \mathrm{m}\end{array}$ & $10^{6} \mathrm{~W} / \mathrm{m}^{2}$ & & $\begin{array}{l}\text { Rising the amplitude to } \\
\text { wavelength relation with } \\
\text { direction of flow and reducing } \\
\text { an aspect ratio of the channels } \\
\text { may increase the performance } \\
\text { of wavy microchannels. }\end{array}$ \\
\hline (Chai et al. 2013) & $\begin{array}{l}\text { Silico } \\
\mathrm{n}\end{array}$ & $\begin{array}{l}\text { Interrupted } \\
\text { channel with } \\
\text { RC ribs }\end{array}$ & $\begin{array}{l}200 \times 100 \times \\
10000 \mu \mathrm{m}\end{array}$ & $\begin{array}{l}1.22 \times 10^{6} \\
\mathrm{~W} / \mathrm{m}^{2}\end{array}$ & $187-715$ & $\begin{array}{l}\text { With } \mathrm{s}=1.3 \mathrm{~mm} \text {, the } \\
\text { microchannel heat sink had } \\
\text { the maximum PEC in the } \\
\text { range observed. }\end{array}$ \\
\hline $\begin{array}{c}\text { (Jawalekar and } \\
\text { Shelare 2020) }\end{array}$ & $\begin{array}{l}\text { Silico } \\
\text { n }\end{array}$ & $\begin{array}{l}\text { Interrupted } \\
\text { channel with } \\
\text { RC, BTR, } \\
\text { FTR, DD, } \\
\text { and EL ribs }\end{array}$ & $\begin{array}{l}200 \times 100 \times \\
10000 \mu \mathrm{m}\end{array}$ & $10^{6} \mathrm{~W} / \mathrm{m}^{2}$ & $187-715$ & $\begin{array}{l}\text { With rib length increment, the } \\
\text { hydrothermal output of the } \\
\text { disrupted microchannel heat } \\
\text { sink decreases. }\end{array}$ \\
\hline
\end{tabular}

Note. BTR: Backward-Triangular, CR: Circular, CV: Curvy, DD: Diamond, DPM: Double path serpentine microchannel, EL: Ellipsoidal, FTR: Forward-Triangular, ID: Interdigitated,: MTC, MSC: Multiple serpentines with two, three and six channels respectively, RC: Rectangular, SMCF: Serpentine MCHS with chevron fins, SN: Sinusoidal, SP: Straight parallel, SPM: Single path serpentine microchannel, SS: Single serpentine, ST: Step, TPM: Triple path serpentine microchannel, TR: Triangular, TZ: Trapezoidal, WV: Wavy, ZZ: Zigzag.

Mostly, choosing a right pattern relies upon factors like geometric requirements and flow rate, and cannot be described for general. Overall interpretation of reviewed articles discussed is offered in this section, and where possible finest geometries have been introduced. Heat transfer rate and pressure drop in the oblique patterns was improved compared to traditional ones. Additionally, the rate of heat transfer into the MCHS is increased with angle of oblique fins and rising pitch. Also, studies shows that hydrothermal performance of these patterns could be improved by staggered arrangement and increased fine porosity.

\subsection{Effect of Structures and Headers of Manifolds of MCHS}

Work on the transfer of heat and pressure drop was conducted theoretically and experimentally in this area. Some variations were found in the multiple microchannels between theoretical and experimental results of friction factor and pressure drop, whereas no variation found into any microchannels (Wang and Peterson 1994a; Harley 1995). This is because of subsistence of maldistribution (MLD) resulting by microchannel separation (Webb 2003; Manikanda et al., 2013), that brings a uneven distribution of temperature in microchannels edges (Nielsen et al. 2012; Nielsen et al., 2013). (Kim et al., 1995) studied an effect of shape of header and suggested triangular header form for better flow distribution as 
compared to other. Moreover, the flow rates in the rectangular header of the last channels were greater than the primary channels that amplified MLD. Rectangular header however improved MLD at higher flow speeds. (Xia et al. 2015) examined microchannel fluid flow having various headers form and different outlet / inlet arrangements. Because of the symmetrical flow distribution they remarked that I-type had greater flow uniformity compared with another cases. In addition, influence of friction in walls reduced the static strain that eventually contributed for a velocities uniform distribution. (Bogojevic et al. 2009) studied an impacts of outlet / inlet opening, and blockage of channel was the product of particle sediment or manufacturing processes that affect the MLD flow, environmental impact and system life (Jensen 2001). The location of the outlet / inlet opening is outside or inside and the location of the channel blockages is top, middle or bottom. Outcomes suggested that less MLD could be generated within position. The overall area of the products is reduced whenever the inlet / outlet is regarded within, and hence the production cycle is increased.

Table 4: summarized all effective parameters for optimizing the design of the manifolds

\begin{tabular}{|c|c|c|c|c|c|}
\hline Reference & parameters & $\begin{array}{c}\text { Inlet \& } \\
\text { Outlet } \\
\text { type }\end{array}$ & $\begin{array}{l}\text { Minimum } \\
\text { MLD }\end{array}$ & Maximum MLD & Outcome \\
\hline $\begin{array}{l}\text { (Datta and } \\
\text { Majumdar } \\
\text { 1983) }\end{array}$ & $\begin{array}{l}\text { U/Z/Mixed- } \\
\text { type }\end{array}$ & $\mathrm{H} \times \mathrm{H} \times \mathrm{H}$ & Mixed & N.A. & $\begin{array}{l}\text { Rising heating charge causes boiling } \\
\text { liquid that generates steam which } \\
\text { leads to increase MLD flow. }\end{array}$ \\
\hline $\begin{array}{c}\text { (Kim et al., } \\
1995)\end{array}$ & $\begin{array}{l}\mathrm{TZ} / \mathrm{TR} / \mathrm{RC} \\
\text { header shape }\end{array}$ & $\mathrm{H} \times \mathrm{H} \times \mathrm{H}$ & TR & $\mathrm{RC}$ & $\begin{array}{l}\text { RC header shape's final channel } \\
\text { flow rate is greater compared to } \\
\text { primary channel, this causes to rise } \\
\text { in MLD flow. }\end{array}$ \\
\hline $\begin{array}{l}\text { (Delsman } \\
\text { et al. 2004) }\end{array}$ & $\begin{array}{l}\mathrm{E} \mathrm{c} / \mathrm{s}, / \mathrm{F} \mathrm{c} / \mathrm{s} \\
/ \mathrm{G} \mathrm{c} / \mathrm{s}, \mathrm{H} \\
\mathrm{c} / \mathrm{s}, \mathrm{I} \mathrm{c} / \mathrm{s} \\
\text { shape } \\
\end{array}$ & $\begin{array}{c}\mathrm{H} \times \mathrm{H} \times \mathrm{H} \\
\mathrm{H} \times \mathrm{H}\end{array}$ & $\begin{array}{l}\text { I into } \\
\text { lower } \\
\text { flowing } \\
\text { rate \& H in } \\
\text { higher } \\
\text { flowing } \\
\text { rate } \\
\end{array}$ & $\begin{array}{l}\mathrm{G} \text { in lower flowing } \\
\text { rate \& } \mathrm{E} \text { in higher } \\
\text { flowing rate }\end{array}$ & $\begin{array}{l}\text { E: Distribution region is triangle } \\
\text { shape. F: } 45^{\circ} \text { angle outlet and inlet } \\
\text { region. G: inlet / outlet region } \\
\text { matched to channels. H: outlet / } \\
\text { Inlet area with more outlet space put } \\
\text { in line to channels. I: outlet / Inlet } \\
\text { region built on both sides in line } \\
\text { with extra space channels. }\end{array}$ \\
\hline $\begin{array}{l}\text { (Chein and } \\
\text { Chen } \\
\text { 2009) }\end{array}$ & $\begin{array}{c}\mathrm{D} / \mathrm{I} / \mathrm{N} / \mathrm{S} / \mathrm{U} / \mathrm{V} \\
\text {-type }\end{array}$ & $\begin{array}{l}\mathrm{H} \times \mathrm{H} \times \mathrm{H} \\
\mathrm{H} \times \mathrm{V} \times \mathrm{V}\end{array}$ & $\begin{array}{c}U \& \mathrm{~V} \\
\text { type }\end{array}$ & S-type & $\begin{array}{l}\text { V-type is more suitable for manifold } \\
\text { design among other cases. }\end{array}$ \\
\hline $\begin{array}{l}\text { (Shelare et } \\
\text { al., 2020) }\end{array}$ & $\begin{array}{l}\text { Right/obtuse } \\
\text { /acute TR } \\
\text { Manifold }\end{array}$ & $\mathrm{V} \times \mathrm{V} \times \mathrm{V}$ & Right, TR & N.A & $\begin{array}{l}\text { Singular in-flow loop pressure drops } \\
\text { are smaller than those of the drops } \\
\text { in frictional pressure which cause } \\
\text { the singular losses to be overlooked. }\end{array}$ \\
\hline $\begin{array}{l}\text { (Sehgal et } \\
\text { al., 2011) }\end{array}$ & P/U/S-type & $\mathrm{V} \times \mathrm{H} \times \mathrm{H}$ & S-type & N.A. & $\begin{array}{l}\text { Nu figures for U-type are } 2 \text { to } 8 \\
\text { percent higher compared to P-type } \\
\text { and } 13 \text { to } 19 \text { percent higher than S- } \\
\text { type. P-type has a minimum friction } \\
\text { factor that makes the use of } \\
\text { microchannel heat sink in the } \\
\text { industry. }\end{array}$ \\
\hline $\begin{array}{l}\text { (Wang et } \\
\text { al. 2011) }\end{array}$ & U/Z-type & $\mathrm{H} \times \mathrm{H}$ & U-type & Z-type & $\begin{array}{l}\text { The pattern of jet flow is important } \\
\text { in MLD flow while gravity effect } \\
\text { has no roles in MLD. }\end{array}$ \\
\hline $\begin{array}{l}\text { (Zeng et } \\
\text { al., 2012) }\end{array}$ & $\begin{array}{l}\text { Right TR } \\
\text { /Oblique TR } \\
\text { Manifold }\end{array}$ & $\mathrm{V} \times \mathrm{V}$ & Right, TR & Oblique TR & $\begin{array}{l}\text { Right, TR Manifold crate narrow } \\
\text { velocity distribution. }\end{array}$ \\
\hline $\begin{array}{l}\text { (Manoj } \\
\text { Siva et al., } \\
\text { 2014) }\end{array}$ & I/U-type & $\mathrm{V} \times \mathrm{V} \times \mathrm{V}$ & I-type & U-type & $\begin{array}{l}\text { By reducing the hydraulic diameter } \\
\text { the flow better distribution obtained. } \\
\text { Increase in flow MLD as number of }\end{array}$ \\
\hline
\end{tabular}




\begin{tabular}{|c|c|c|c|c|c|}
\hline & & & & & $\begin{array}{l}\text { channels increases and the multiple } \\
\text { area decreases. }\end{array}$ \\
\hline $\begin{array}{l}\text { (Manikand } \\
\text { a et al., } \\
\text { 2013) }\end{array}$ & $\begin{array}{c}\text { I/C/V/Z/U- } \\
\text { type \& RC / } \\
\text { TR /3 type } \\
\text { TZ inlet } \\
\text { header shape } \\
\& \mathrm{RC} / \mathrm{TR} \\
\text { /2 type TZ } \\
\text { inlet header } \\
\text { shape }\end{array}$ & $\begin{array}{l}\mathrm{V} \times \mathrm{V} \times \mathrm{V} \\
\times \mathrm{H} \times \mathrm{H}\end{array}$ & $\begin{array}{l}\text { C-type \& } \\
\text { TR (inlet) } \\
\text { \& TZ } \\
\text { (outlet) }\end{array}$ & $\begin{array}{l}\text { V-type \& TZ No.2 } \\
\text { (inlet) \& TR (outlet) }\end{array}$ & $\begin{array}{l}\text { I-type and Max have a symmetrical } \\
\text { distribution. } \cdot \text { P belongs to the Z- } \\
\text { type during min. Four outlet and } \\
\text { five inlets headers, set respectively } \\
\text { by RC inlet and outlet. }\end{array}$ \\
\hline $\begin{array}{l}\text { (Wang and } \\
\text { Wang } \\
2015 \text { ) }\end{array}$ & U/Z-type & $\mathrm{H} \times \mathrm{H}$ & U-type & Z-type & $\begin{array}{l}\text { Z-Type approaches flow } \\
\text { propagation as quickly as U-Type } \\
\text { which is awfully useful for efficient } \\
\text { design. }\end{array}$ \\
\hline $\begin{array}{c}\text { (Xia et al. } \\
2015)\end{array}$ & $\begin{array}{l}\text { TR / TZ / } \\
\text { RC header } \\
\text { shape \& } \\
\text { C/I/Z-type }\end{array}$ & $\mathrm{V} \times \mathrm{V} \times \mathrm{V}$ & $\begin{array}{c}\mathrm{RC} \& \mathrm{I}- \\
\text { type }\end{array}$ & TR \& Z-type & $\begin{array}{l}\text { Branching fluid increases static } \\
\text { pressure, and friction factor impact } \\
\text { reduces the Rec header pressure } \\
\text { which results in consistent velocity. }\end{array}$ \\
\hline $\begin{array}{l}\text { (Anbumee } \\
\text { nakshi and } \\
\text { Thansekha } \\
\text { r 2016) }\end{array}$ & $\begin{array}{l}\text { Rec. / TZ } \\
\text { /TR header } \\
\text { shape } \\
\end{array}$ & $\begin{array}{c}\mathrm{H} / \mathrm{H} / \mathrm{H} \& \\
\mathrm{~V} / \mathrm{V} / \mathrm{V}\end{array}$ & $\begin{array}{l}\text { RC in high } \\
\text { flow rat \& } \\
\text { TZ / TR in } \\
\text { low flow } \\
\text { rate } \\
\end{array}$ & $\begin{array}{l}\mathrm{RC} \text { in low flow rat } \& \\
\mathrm{TZ} / \mathrm{TR} \text { In high flow } \\
\text { rate }\end{array}$ & $\begin{array}{l}\text { From all situations the vertical flow } \\
\text { configuration produces fewer MLD } \\
\text { leaking than that of the (Horizontal) } \\
\text { inline configuration. }\end{array}$ \\
\hline
\end{tabular}

Ultimately, to conclude for this segment the I-type may be most suitable for achieving symmetrical flow. In addition, minimum MLD was observed in rectangular header a shape that increases the heat transfer coefficient. In general, Re number, form of inlet / outlet and heat sink size need these parameters to be consider in order to achieve header shapes and optimum arrangements for decreasing MLD.

\subsection{Effect of Nanofluid for MCHS:}

Table 5 provides a description of the microchannel geometric parameters, the working fluid and the operating conditions used by numerous investigators,

Table 5: Summarized geometric parameter of microchannels and working fluid

\begin{tabular}{|c|c|c|c|}
\hline References & Working fluid & $\begin{array}{c}\text { Material } \\
\text { of heat sink }\end{array}$ & Particles \\
\hline $\begin{array}{l}\text { (B. X. Wang and } \\
\text { Peterson 1994b) }\end{array}$ & Water & Stainless steel & \\
\hline (Choi and Cho 2001) & Water & $\mathrm{Cu}$ & $\begin{array}{c}5 \% \text { Paraffin slurry } \\
\text { as PCM }\end{array}$ \\
\hline (Jang and Choi 2006) & Water & $\mathrm{Si}$ & $\begin{array}{l}\text { copper nano } \\
\text { particles and } \\
\text { diamond nano } \\
\text { particles }\end{array}$ \\
\hline (Nguyen et al. 2007) & Water & $\mathrm{Cu}$ & $\mathrm{Al}_{2} \mathrm{O}_{3}$ \\
\hline ( Lin et al., 2011) & Water & & $\mathrm{Al}_{2} \mathrm{O}_{3}$ \\
\hline (Escher et al. 2011) & Water & $\mathrm{Si}$ & Silica $\left(\mathrm{SiO}_{2}\right)$ \\
\hline (Mo et al. 2012) & Water & & $\mathrm{TiO}_{2}$ \\
\hline (Raveshi et al. 2013) & $\begin{array}{l}\text { Water and ethylene } \\
\text { glycol }\end{array}$ & $\mathrm{Cu}$ & Alumina \\
\hline (Yiamsawas et al. 2013) & $\begin{array}{c}\text { Ethylene glycol and } \\
\text { water }\end{array}$ & & $\mathrm{TiO}_{2}$ and $\mathrm{Al}_{2} \mathrm{O}_{3}$ \\
\hline
\end{tabular}




\begin{tabular}{|c|c|c|c|}
\hline (Fan et al. 2013) & $\begin{array}{l}\text { Paraffin-based } \\
\text { nanocomposite }\end{array}$ & & Carbon nanofillers \\
\hline (M. Li 2013) & Paraffin & & Nano-graphite \\
\hline (Mahmoud et al. 2013) & paraffin wax PCM & Al T6- 6061 & \\
\hline (Suganthi et al., 2014) & $\begin{array}{c}\text { Ethylene glycol and } \\
\text { water }\end{array}$ & & $\mathrm{ZnO}$ \\
\hline $\begin{array}{l}\text { (Marcinichen et al. } \\
\text { 2014) }\end{array}$ & $\mathrm{R} 134 \mathrm{a}$ & $\mathrm{Cu}$ & \\
\hline (Bayomy et al., 2016) & Water & $\mathrm{Al}$ & \\
\hline (N. Zhou et al. 2017) & Water & $\mathrm{Cu}$ & \\
\hline (Mowade et al., 2020) & Water & $\mathrm{Cu}$ & $\begin{array}{c}\text { Multi-walled } \\
\text { carbon nanotubes }\end{array}$ \\
\hline (Bahiraei et al. 2019) & Water & $\mathrm{Cu}$ & $\begin{array}{l}\text { Green ecofriendly } \\
\text { nanofluids }\end{array}$ \\
\hline (Hadavand et al. 2019) & Water & $\mathrm{Si}$ & Silver $(\mathrm{Ag})$ \\
\hline
\end{tabular}

From Table 5 it can be concluded that the number of research were conducted on test sections based on copper and silicon substrates. Due to its high thermal conductivity, copper is a very common material in thermal process equipment and silicone is a strong semiconductor widely utilized in the electronics and VLSI industry. Also from Table 5, that the majority of studies were conducted by refrigerant or water as working fluid.

\section{CONCLUSIONS AND FUTURE SCOPE}

Various liquid cooling techniques was used for heat transfer efficiency improvement into electronics equipments. Heat sinks geometry and nanofluids assumes a crucial role while enhancing cooling system capacity. Critical parameters which can be impacted due to the thermal-hydraulic efficiency are pressure drop, mean temperature, and coefficient of heat transfer, flow and temperature uniformity, as well as Nusselt number. Important data are extracted at the end of each part of paper. Parameters of geometry are broken down into three significant parts that are summed up beneath.

- Cross-section shape in microchannels has been addressed in section 2.2. According to Table 5, in microchannels heat sinks, rectangular shapes have more significance. It means that the rectangular form absorbs extra heat which causes less pressure rises, while in some situations the efficiency of the rectangular shape was greater than that of other shapes by about 50 percent.

- By analyzing a number of different papers, it is noted that geometric parameters assume to have an imperative role in heat sinks efficiency within each of the patterns studied. In periodic patterns, for example, the amplitude and length of the periodic pattern, periodic pattern shape, number of spiral channels, and the spiral patterns, may influence performance of those heat sinks. Therefore effectual parameters for efficiency of heat sink should be investigated in the design for optimized performance of patterns discussed.

- In Manifold study, it was concluded that maldistribution along the microchannel should be minimized to achieve a specific hot spots and an optimal design for achieving optimum performance. Various parameters are important in performing on MLD into the microchannel such as inlet / outlet arrangements, header shape, inlet configurations, inlet / outlet position, and corner curvature radius. U-type, however, provides better distribution; sometimes, a maximum drop in pressure is produced. I-type have a symmetrical type of flow therefore can be proffered to use.

- One of the major drawbacks is the microchannel-based liquid cooling that, despite its supremacy, is not yet 
commercialized for compact devices like laptops but most studies have been conducted for estimation of the microchannel performance index alone. Research on a composite output index was also not much seen by performing an accelerated analysis with micropump, flow losses, and head losses.

- Continuous developments in microfabrication further inform us that microchannel heat sinks are a desirable substitute for heat pipes and fins in compact electronic cooling systems. This is only feasible in conceptual terms when related functional tools of the microchannels are also taken into consideration in the analysis as a single entity. Cooling with microchannels throughout a single phase holds good but addition of nanoparticles like $\mathrm{Al}_{2} \mathrm{O}_{3}$, $\mathrm{SiO}_{2}$ or $\mathrm{TiO}_{2}$ an effective option for dissipating high-power systems.

- Most of experiments on microtubes or microchannels of rectangular section has been done. Also few studies on various cross sections such as hexagonal, V-shape, trapezoidal etc has been done. It would be important to aware channel geometry impact on the characteristics of heat transfer, and particularly on instability. In addition, refrigerants such as R600a and R290 were not explored as microchannel working fluid.

- Finally, researchers will think about an implementation of MCHS primarily to improve the design of the MCHS. That means they have to specify which parameters are more important than other things, i.e. the pressure drops, coefficient of heat transfer, thermal resistance, MLD, and PEC. After define chip types (microchannel or micropin-fin). Researchers then select which sequence, manifold and cross-section they are concerned, respectively. The designer would also think about the manufacturing limitations prior to carrying out information design.

\section{REFERENCES}

1. Abdoli, Abas, Gianni Jimenez, and George S. Dulikravich. 2015. "Thermo-Fluid Analysis of Micro Pin-Fin Array Cooling Configurations for High Heat Fluxes with a Hot Spot." International Journal of Thermal Sciences 90: 290-97. https://doi.org/10.1016/j.ijthermalsci.2014.12.021.

2. Ahmed, Hamdi E., M. I. Ahmed, Islam M.F. Seder, and B. H. Salman. 2016. "Experimental Investigation for Sequential Triangular Double-Layered Microchannel Heat Sink with Nanofluids." International Communications in Heat and Mass Transfer 77: 104-15. https://doi.org/10.1016/j.icheatmasstransfer.2016.06.010.

3. Akademia Baru, Penerbit, S B Abubakar, and N A Che Sidik. 2015. "Numerical Prediction of Laminar Nanofluid Flow in Rectangular Microchannel Heat Sink." Journal of Advanced Research in Fluid Mechanics and Thermal Sciences ISSN 7 (1): $29-38$.

4. Al-Neama, Ahmed F., Nikil Kapur, Jonathan Summers, and Harvey M. Thompson. 2017. "An Experimental and Numerical Investigation of the Use of Liquid Flow in Serpentine Microchannels for Microelectronics Cooling." Applied Thermal Engineering 116: 709-23. https://doi.org/10.1016/j.applthermaleng.2017.02.001.

5. Al-Neama, Ahmed F., Zinedine Khatir, Nikil Kapur, Jonathan Summers, and Harvey M. Thompson. 2018. "An Experimental and Numerical Investigation of Chevron Fin Structures in Serpentine Minichannel Heat Sinks." International Journal of Heat and Mass Transfer 120: 1213-28. https://doi.org/10.1016/j.ijheatmasstransfer.2017.12.092.

6. Alfaryjat, A. A., H. A. Mohammed, Nor Mariah Adam, M. K.A. Ariffin, and M. I. Najafabadi. 2014. "Influence of Geometrical Parameters of Hexagonal, Circular, and Rhombus Microchannel Heat Sinks on the Thermohydraulic Characteristics." International Communications in Heat and Mass Transfer 52: 121-31. https://doi.org/10.1016/j.icheatmasstransfer.2014.01.015. 
7. Almoli, Ali, Adam Thompson, Nikil Kapur, Jonathan Summers, Harvey Thompson, and George Hannah. 2012. “Computational Fluid Dynamic Investigation of Liquid Rack Cooling in Data Centres.” Applied Energy 89 (1): 150-55. https://doi.org/10.1016/j.apenergy.2011.02.003.

8. Anbumeenakshi, C., and M. R. Thansekhar. 2016. "Experimental Investigation of Header Shape and Inlet Configuration on Flow Maldistribution in Microchannel." Experimental Thermal and Fluid Science 75: 156-61. https://doi.org/10.1016/j.expthermflusci.2016.02.004.

9. Arani, Ali Akbar Abbasian, Omid Ali Akbari, Mohammad Reza Safaei, Ali Marzban, Abdullah A.A.A. Alrashed, Gholam Reza Ahmadi, and Truong Khang Nguyen. 2017. "Heat Transfer Improvement of Water/Single-Wall Carbon Nanotubes (SWCNT) Nanofluid in a Novel Design of a Truncated Double-Layered Microchannel Heat Sink." International Journal of Heat and Mass Transfer 113: 780-95. https://doi.org/10.1016/j.ijheatmasstransfer.2017.05.089.

10. Bahiraei, Mehdi, and Saeed Heshmatian. 2017. "Optimizing Energy Efficiency of a Specific Liquid Block Operated with Nanofluids for Utilization in Electronics Cooling: A Decision-Making Based Approach." Energy Conversion and Management 154 (August): 180-90. https://doi.org/10.1016/j.enconman.2017.10.055.

11. Bahiraei, Mehdi, Saeed Heshmatian, Marjan Goodarzi, and Hossein Moayedi. 2019. "CFD Analysis of Employing a Novel Ecofriendly Nanofluid in a Miniature Pin Fin Heat Sink for Cooling of Electronic Components: Effect of Different Configurations." Advanced Powder Technology 30 (11): 2503-16. https://doi.org/10.1016/j.apt.2019.07.029.

12. Bajura, R. A., and E. H. Jones. 1976. "Flow Distribution Manifolds." Journal of Fluids Engineering, Transactions of the ASME 98 (4): 654-65. https://doi.org/10.1115/1.3448441.

13. Bayomy, A. M., M. Z. Saghir, and T. Yousefi. 2016. "Electronic Cooling Using Water Flow in Aluminum Metal Foam Heat Sink: Experimental and Numerical Approach." International Journal of Thermal Sciences 109: 182-200. https://doi.org/10.1016/j.ijthermalsci.2016.06.007.

14. Beach, Ray, William J. Benett, Barry L. Freitas, D. Mundinger, Brian J. Comaskey, Richard W. Solarz, and Mark A. Emanuel. 1992. “Modular Microchannel Cooled Heatsinks for High Average Power Laser Diode Arrays.” IEEE Journal of Quantum Electronics 28 (4): 966-76. https://doi.org/10.1109/3.135215.

15. Bogojevic, Dario, Khellil Sefiane, Anthony J. Walton, John R.E. Christy, Gerard Cummins, and Huamao Lin. 2009. "Investigation of Flow Distribution in Microchannels Heat Sinks." Heat Transfer Engineering 30 (13): 1049-57. https://doi.org/10.1080/01457630902921287.

16. Capua H, Mario Di, Rodrigo Escobar, A. J. Diaz, and Amador M. Guzmán. 2018. "Enhancement of the Cooling Capability of a High Concentration Photovoltaic System Using Microchannels with Forward Triangular Ribs on Sidewalls.” Applied Energy 226 (April): 160-80. https://doi.org/10.1016/j.apenergy.2018.05.052.

17. Chai, Lei, Guodong Xia, Mingzheng Zhou, Jian Li, and Jingzhi Qi. 2013. "Optimum Thermal Design of Interrupted Microchannel Heat Sink with Rectangular Ribs in the Transverse Microchambers.” Applied Thermal Engineering 51 (1-2): 880-89. https://doi.org/10.1016/j.applthermaleng.2012.10.037.

18. Chein, Reiyu, and Janghwa Chen. 2009. "Numerical Study of the Inlet/Outlet Arrangement Effect on Microchannel Heat Sink Performance." International Journal of Thermal Sciences 48 (8): 1627-38. https://doi.org/10.1016/j.ijthermalsci.2008.12.019.

19. Chen, Tailian, and Suresh V. Garimella. 2011. "Local Heat Transfer Distribution and Effect of Instabilities during Flow Boiling in a Silicon Microchannel Heat Sink.” International Journal of Heat and Mass Transfer 54 (15-16): 3179-90. https://doi.org/10.1016/j.ijheatmasstransfer.2011.04.012.

20. Choi, Mingoo, and Keumnam Cho. 2001. "Effect of the Aspect Ratio of Rectangular Channels on the Heat Transfer and 
Hydrodynamics of Paraffin Slurry Flow." International Journal of Heat and Mass Transfer 44 (1): 55-61. https://doi.org/10.1016/S0017-9310(00)00095-8.

21. Datta, A. B., and A. K. Majumdar. 1983. “Une Procedure de Calcul de La Repartition d'un Ecoulement Diphasique Dans Des Distributions Avec Ou sans Transfert Thermique." International Journal of Heat and Mass Transfer 26 (9): 1321-28. https://doi.org/10.1016/S0017-9310(83)80063-5.

22. Delsman, E. R., A. Pierik, M. H.J.M. De Croon, G. J. Kramer, and J. C. Schouten. 2004. "Microchannel Plate Geometry Optimization for Even Flow Distribution at High Flow Rates.” Chemical Engineering Research and Design 82 (2): $267-73$. https://doi.org/10.1205/026387604772992864.

23. Dix, Joe, Amir Jokar, and Robert Martinsen. 2008. "Enhanced Microchannel Cooling for High-Power Semiconductor Diode Lasers.” High-Power Diode Laser Technology and Applications VI 6876: 687606. https://doi.org/10.1117/12.762172.

24. Duangthongsuk, Weerapun, and Somchai Wongwises. 2015. "A Comparison of the Heat Transfer Performance and Pressure Drop of Nanofluid-Cooled Heat Sinks with Different Miniature Pin Fin Configurations.” Experimental Thermal and Fluid Science 69: 111-18. https://doi.org/10.1016/j.expthermflusci.2015.07.019.

25. Ebrahimi, Amin, Farhad Rikhtegar, Amin Sabaghan, and Ehsan Roohi. 2016. "Heat Transfer and Entropy Generation in a Microchannel with Longitudinal Vortex Generators Using Nanofluids.” Energy 101: 190-201. https://doi.org/10.1016/j.energy.2016.01.102.

26. Escher, W., T. Brunschwiler, N. Shalkevich, A. Shalkevich, T. Burgi, B. Michel, and D. Poulikakos. 2011. "On the Cooling of Electronics with Nanofluids." Journal of Heat Transfer 133 (5): 1-11. https://doi.org/10.1115/1.4003283.

27. Fan, Li Wu, Xin Fang, Xiao Wang, Yi Zeng, Yu Qi Xiao, Zi Tao Yu, Xu Xu, Ya Cai Hu, and Ke Fa Cen. 2013. "Effects of Various Carbon Nanofillers on the Thermal Conductivity and Energy Storage Properties of Paraffin-Based Nanocomposite Phase Change Materials.” Applied Energy 110: 163-72. https://doi.org/10.1016/j.apenergy.2013.04.043.

28. Ghale, Z. Yari, M. Haghshenasfard, and M. Nasr Esfahany. 2015. "Investigation of Nanofluids Heat Transfer in a Ribbed Microchannel Heat Sink Using Single-Phase and Multiphase CFD Models." International Communications in Heat and Mass Transfer 68: 122-29. https://doi.org/10.1016/j.icheatmasstransfer.2015.08.012.

29. Gunnasegaran, P., H. A. Mohammed, N. H. Shuaib, and R. Saidur. 2010. "The Effect of Geometrical Parameters on Heat Transfer Characteristics of Microchannels Heat Sink with Different Shapes.” International Communications in Heat and Mass Transfer 37 (8): 1078-86. https://doi.org/10.1016/j.icheatmasstransfer.2010.06.014.

30. Hadavand, Masoud, Shahrouz Yousefzadeh, Omid Ali Akbari, Farzad Pourfattah, Hoang Minh Nguyen, and Amin Asadi. 2019. “A Numerical Investigation on the Effects of Mixed Convection of Ag-Water Nanofluid inside a Sim-Circular Lid-Driven Cavity on the Temperature of an Electronic Silicon Chip." Applied Thermal Engineering 162 (April): 114298. https://doi.org/10.1016/j.applthermaleng.2019.114298.

31. Harley, John C. 1995. "Gas Flow in Micr-Channels Gas Flow in Micr-Channels.” Journal of Fluid Mechanics 28: 257-74.

32. Hetsroni, G., A. Mosyak, E. Pogrebnyak, and L. P. Yarin. 2005. "Heat Transfer in Micro-Channels: Comparison of Experiments with Theory and Numerical Results.” International Journal of Heat and Mass Transfer 48 (25-26): 5580-5601. https://doi.org/10.1016/j.ijheatmasstransfer.2005.05.041.

33. Hua, Junye, Gui Li, Xiaobao Zhao, Qihe Li, and Jiao Hu. 2016. "Study on the Flow Resistance Performance of Fluid Cross Various Shapes of Micro-Scale Pin Fin.” Applied Thermal Engineering 107: 768-75. https://doi.org/10.1016/j.applthermaleng.2016.07.048. 
34. Husain, Afzal, and Kwang-yong Kim. 2009. "Microchannel Heat Sinking: Analysis and Optimization.” In Fluid Machinery and Fluid Mechanics, 185-90. https://doi.org/10.1007/978-3-540-89749-1_25.

35. Hussien, Ahmed A., Mohd Z. Abdullah, and Moh'd A. Al-Nimr. 2016. "Single-Phase Heat Transfer Enhancement in Micro/Minichannels Using Nanofluids: Theory and Applications.” Applied Energy 164: 733-55. https://doi.org/10.1016/j.apenergy.2015.11.099.

36. Islam, M N, M N Islam, and M R A Beg. 2004. "The Fuel Properties of Pyrolysis Liquid Derived from Urban Solid Wastes in Bangladesh” 92: 181-86. https://doi.org/10.1016/j.biortech.2003.08.009.

37. Jang, Seok Pil, and Stephen U.S. Choi. 2006. “Cooling Performance of a Microchannel Heat Sink with Nanofluids.” Applied Thermal Engineering 26 (17-18): 2457-63. https://doi.org/10.1016/j.applthermaleng.2006.02.036.

38. Jawalekar, S. B., and S. D. Shelare. 2020. Development and performance analysis of low cost combined harvester for rabicrops. Agricultural Engineering International:CIGR Journal, 22 (1):197-201.

39. Jensen, Klavs F. 2001. "Microreaction Engineering - Is Small Better?.Pdf." Chemical Engineering Science 56: $293-303$.

40. Kakac, S. 2012. Heat Exchangers: Selection, Rating, and Thermal Design. 4th ed. CRC Press.

41. Kakaç, S. Yüncü, H., Hijikata, K. 2012. "Cooling of electronic systems", Springer Science \& Business Media,.

42. Khoshvaght-Aliabadi, M., S. M. Hassani, and S. H. Mazloumi. 2017a. "Comparison of Hydrothermal Performance between Plate Fins and Plate-Pin Fins Subject to Nanofluid-Cooled Corrugated Miniature Heat Sinks.” Microelectronics Reliability 70: 84-96. https://doi.org/10.1016/j.microrel.2017.01.005.

43. "Performance Enhancement of Straight and Wavy Miniature Heat Sinks Using Pin-Fin Interruptions and Nanofluids." Chemical Engineering and Processing: Process Intensification 122: 90-108. https://doi.org/10.1016/j.cep.2017.10.002.

44. Khoshvaght-Aliabadi, M., S. M. Hassani, S. H. Mazloumi, and M. Nekoei. 2017. "Effects of Nooks Configuration on Hydrothermal Performance of Zigzag Channels for Nanofluid-Cooled Microelectronic Heat Sink." Microelectronics Reliability 79 (May): 153-65. https://doi.org/10.1016/j.microrel.2017.10.024.

45. Khoshvaght-Aliabadi, Morteza, and Farnaz Nozan. 2016. "Water Cooled Corrugated Minichannel Heat Sink for Electronic Devices: Effect of Corrugation Shape." International Communications in Heat and Mass Transfer 76: 188-96. https://doi.org/10.1016/j.icheatmasstransfer.2016.05.021.

46. Kim, Sooyoun, Eunsoo Choi, and Young I. Cho. 1995. "The Effect of Header Shapes on the Flow Distribution in a Manifold for Electronic Packaging Applications." International Communications in Heat and Mass Transfer 22 (3): 329-41. https://doi.org/10.1016/0735-1933(95)00024-S.

47. Kleiner, Michael B., Stefan A. Kuehn, and Karl Haberger. 1995. "High Performance Forced Air Cooling Scheme Employing Microchannel Heat Exchangers.” IEEE Transactions on Components, Packaging, and Manufacturing Technology. Part A 18 (4): 795-804. https://doi.org/10.1109/95.477466.

48. Lee, Jae Yong, Moo Hwan Kim, Massoud Kaviany, and Sang Young Son. 2011. "Bubble Nucleation in Microchannel Flow Boiling Using Single Artificial Cavity.” International Journal of Heat and Mass Transfer 54 (25-26): 5139-48. https://doi.org/10.1016/j.ijheatmasstransfer.2011.08.042.

49. Lee, Poh Seng, Suresh V. Garimella, and Dong Liu. 2005. "Investigation of Heat Transfer in Rectangular Microchannels." International Journal of Heat and Mass Transfer 48 (9): 1688-1704. https://doi.org/10.1016/j.ijheatmasstransfer.2004.11.019.

50. Li, Min. 2013. “A Nano-Graphite/Paraffin Phase Change Material with High Thermal Conductivity.” Applied Energy 106: 25-30. https://doi.org/10.1016/j.apenergy.2013.01.031. 
51. Li, Peiwen, Devasubramaniam Coopamah, and Jeong Pill Ki. 2008. "Uniform Distribution of Species in Fuel Cells Using a Multiple Flow Bifurcation Design.” Proceedings of the 6th International Conference on Fuel Cell Science, Engineering, and Technology, 897-902. https://doi.org/10.1115/FuelCell2008-65106.

52. Lin, Cherng Yuan, Jung Chang Wang, and Teng Chieh Chen. 2011. "Analysis of Suspension and Heat Transfer Characteristics of Al2O3 Nanofluids Prepared through Ultrasonic Vibration.” Applied Energy 88 (12): 4527-33. https://doi.org/10.1016/j.apenergy.2011.05.035.

53. Lin, Lin, Jun Zhao, Gui Lu, Xiao Dong Wang, and Wei Mon Yan. 2017. "Heat Transfer Enhancement in Microchannel Heat Sink by Wavy Channel with Changing Wavelength/Amplitude." International Journal of Thermal Sciences 118: 423-34. https://doi.org/10.1016/j.ijthermalsci.2017.05.013.

54. Liu, Hong, and Peiwen Li. 2013. "Even Distribution/Dividing of Single-Phase Fluids by Symmetric Bifurcation of Flow Channels.” International Journal of Heat and Fluid Flow 40: 165-79. https://doi.org/10.1016/j.ijheatfluidflow.2013.01.011.

55. Mahmoud, Saad, Aaron Tang, Chin Toh, Raya AL-Dadah, and Sein Leung Soo. 2013. "Experimental Investigation of Inserts Configurations and PCM Type on the Thermal Performance of PCM Based Heat Sinks.” Applied Energy 112: 1349-56. https://doi.org/10.1016/j.apenergy.2013.04.059.

56. Manikanda Kumaran, R., G. Kumaraguruparan, and T. Sornakumar. 2013. "Experimental and Numerical Studies of Header Design and Inlet/Outlet Configurations on Flow Mal-Distribution in Parallel Micro-Channels." Applied Thermal Engineering 58 (1-2): 205-16. https://doi.org/10.1016/j.applthermaleng.2013.04.026.

57. Manoj Siva, V., Arvind Pattamatta, and Sarit Kumar Das. 2014. "Investigation on Flow Maldistribution in Parallel Microchannel Systems for Integrated Microelectronic Device Cooling." IEEE Transactions on Components, Packaging and Manufacturing Technology 4 (3): 438-50. https://doi.org/10.1109/TCPMT.2013.2284291.

58. Marcinichen, Jackson Braz, Duan Wu, Stephan Paredes, John R. Thome, and Bruno Michel. 2014. "Dynamic Flow Control and Performance Comparison of Different Concepts of Two-Phase on-Chip Cooling Cycles." Applied Energy 114: 179-91. https://doi.org/10.1016/j.apenergy.2013.09.018.

59. Mei, Fanghua, Pritish R. Parida, Jing Jiang, Wen Jin Meng, and Srinath V. Ekkad. 2008. "Fabrication, Assembly, and Testing of $\mathrm{Cu}$ - and Al-Based Microchannel Heat Exchangers.” Journal of Microelectromechanical Systems 17 (4): 869-81. https://doi.org/10.1109/JMEMS.2008.924276.

60. Mo, Songping, Ying Chen, Lisi Jia, and Xianglong Luo. 2012. "Investigation on Crystallization of TiO2-Water Nanofluids and Deionized Water.” Applied Energy 93 (100): 65-70. https://doi.org/10.1016/j.apenergy.2011.07.014.

61. Mohamad Noh, Nur Hazwani, and Nor Azwadi Che Sidik. 2014. "Numerical Simulation of Nanofluids for Improved Cooling Efficiency in Microchannel Heat Sink." Applied Mechanics and Materials 695 (1): 403-7. https://doi.org/10.4028/www.scientific.net/amm.695.403.

62. Mohammed, H. A., P. Gunnasegaran, and N. H. Shuaib. 2011a. "Influence of Channel Shape on the Thermal and Hydraulic Performance of Microchannel Heat Sink." International Communications in Heat and Mass Transfer 38 (4): 474-80. https://doi.org/10.1016/j.icheatmasstransfer.2010.12.031.

63. Mowade S., Waghmare S., Shelare S., Tembhurkar C. (2020) Mathematical Model for Convective Heat Transfer Coefficient During Solar Drying Process of Green Herbs. In: Iyer B., Deshpande P., Sharma S., Shiurkar U. (eds) Computing in Engineering and Technology. Advances in Intelligent Systems and Computing, vol 1025. Springer, Singapore

64. Mundinger, D., R. Beach, W. Benett, R. Solarz, W. Krupke, R. Staver, and D. Tuckerman. 1988. "Demonstration of HighPerformance Silicon Microchannel Heat Exchangers for Laser Diode Array Cooling.” Applied Physics Letters 53 (12): 1030- 
32. https://doi.org/10.1063/1.100055.

65. Nguyen, Cong Tam, Gilles Roy, Christian Gauthier, and Nicolas Galanis. 2007. "Heat Transfer Enhancement Using Al2O3Water Nanofluid for an Electronic Liquid Cooling System.” Applied Thermal Engineering 27 (8-9): 1501-6. https://doi.org/10.1016/j.applthermaleng.2006.09.028.

66. Nielsen, K. K., K. Engelbrecht, and C. R.H. Bahl. 2013. "The Influence of Flow Maldistribution on the Performance of Inhomogeneous Parallel Plate Heat Exchangers.” International Journal of Heat and Mass Transfer 60 (1): $432-39$. https://doi.org/10.1016/j.ijheatmasstransfer.2013.01.018.

67. Nielsen, K. K., K. Engelbrecht, D. V. Christensen, J. B. Jensen, A. Smith, and C. R.H. Bahl. 2012. "Degradation of the Performance of Microchannel Heat Exchangers Due to Flow Maldistribution.” Applied Thermal Engineering 40: $236-47$. https://doi.org/10.1016/j.applthermaleng.2012.02.019.

68. Omer, Abdeen Mustafa. 2008. "Energy, Environment and Sustainable Development." Renewable and Sustainable Energy Reviews 12 (9): 2265-2300. https://doi.org/10.1016/j.rser.2007.05.001.

69. Papautsky, Ian, John Brazzle, Harold Swerdlow, and A. Bruno Frazier. 1998. "A Low-Temperature IC-Compatible Process for Fabricating Surface-Micromachined Metallic Microchannels.” Journal of Microelectromechanical Systems 7 (2): $267-73$. https://doi.org/10.1109/84.679398.

70. Perret, C., Ch Schaeffer, and J. Boussey. 1998. "Microchannel Integrated Heat Sinks in Silicon Technology.” Conference Record - IAS Annual Meeting (IEEE Industry Applications Society) 2: 1051-55. https://doi.org/10.1109/ias.1998.730276.

71. Phillips, Richard. 1988. "Microchannel Heat Sinks." The Lincoin Laboratory Journal 1 (1): $31-48$. https://doi.org/10.1201/9781420050905.ch32.

72. Rakhsha, Milad, Farzan Akbaridoust, Abbas Abbassi, and Saffar Avval Majid. 2015. "Experimental and Numerical Investigations of Turbulent Forced Convection Flow of Nano-Fluid in Helical Coiled Tubes at Constant Surface Temperature." Powder Technology 283: 178-89. https://doi.org/10.1016/j.powtec.2015.05.019.

73. Raveshi, Mohammad Reza, Ali Keshavarz, Mohammad Salemi Mojarrad, and Shayan Amiri. 2013. "Experimental Investigation of Pool Boiling Heat Transfer Enhancement of Alumina-Water-Ethylene Glycol Nanofluids.” Experimental Thermal and Fluid Science 44: 805-14. https://doi.org/10.1016/j.expthermflusci.2012.09.025.

74. Sakanova, Assel, and King Jet Tseng. 2018. "Comparison of Pin-Fin and Finned Shape Heat Sink for Power Electronics in Future Aircraft.” Applied Thermal Engineering 136: 364-74. https://doi.org/10.1016/j.applthermaleng.2018.03.020.

75. Sehgal, S. S., K. Murugesan, and S. K. Mohapatra. 2011. "Experimental Investigation of the Effect of Flow Arrangements on the Performance of a Micro-Channel Heat Sink.” Experimental Heat Transfer 24 (3): $215-33$. https://doi.org/10.1080/08916152.2010.523808.

76. Shelare S.D., Kumar R., Khope P.B. (2021) Formulation of a Mathematical Model for Quantity of Deshelled Nut in Charoli Nut Deshelling Machine. In: Prakash C., Krolczyk G., Singh S., Pramanik A. (eds) Advances in Metrology and Measurement of Engineering Surfaces. Lecture Notes in Mechanical Engineering. Springer, Singapore

77. Sohel Murshed, S. M., and C. A. Nieto de Castro. 2017. "A Critical Review of Traditional and Emerging Techniques and Fluids for Electronics Cooling.” Renewable and Sustainable Energy Reviews. Elsevier Ltd. https://doi.org/10.1016/j.rser.2017.04.112.

78. Suganthi, K. S., V. Leela Vinodhan, and K. S. Rajan. 2014. "Heat Transfer Performance and Transport Properties of ZnOEthylene Glycol and ZnO-Ethylene Glycol-Water Nanofluid Coolants.” Applied Energy 135: 548-59. 
https://doi.org/10.1016/j.apenergy.2014.09.023.

79. Sui, Y., P. S. Lee, and C. J. Teo. 2011. "An Experimental Study of Flow Friction and Heat Transfer in Wavy Microchannels with Rectangular Cross Section." International Journal of Thermal Sciences 50 (12): $2473-82$. https://doi.org/10.1016/j.ijthermalsci.2011.06.017.

80. Sui, Y., C. J. Teo, P. S. Lee, Y. T. Chew, and C. Shu. 2010. "Fluid Flow and Heat Transfer in Wavy Microchannels." International Journal of Heat and Mass Transfer $53 \quad$ (13-14): $2760-72$. https://doi.org/10.1016/j.ijheatmasstransfer.2010.02.022.

81. Taylor, Robert A., and Gary L. Solbrekken. 2008. "Comprehensive System-Level Optimization of Thermoelectric Devices for Electronic Cooling Applications." IEEE Transactions on Components and Packaging Technologies 31 (1): 23-31. https://doi.org/10.1109/TCAPT.2007.906333.

82. Tomor, András, and Gergely Kristóf. 2017. “Hydraulic Loss of Finite Length Dividing Junctions.” Journal of Fluids Engineering, Transactions of the ASME 139 (3): 1-11. https://doi.org/10.1115/1.4034876.

83. Tuckerman, D B. 1981. “High-Performance Heat Sinking for VLSI." IEEE ELECTRON DEVICE LETTERS 2 (5): 126-29. https://doi.org/10.1177/0164027595174002.

84. Tullius, Jami F., Robert Vajtai, and Yildiz Bayazitoglu. 2011. "A Review of Cooling in Microchannels." Heat Transfer Engineering 32 (7-8): 527-41. https://doi.org/10.1080/01457632.2010.506390.

85. Waghmare, S. N., S. D. Shelare, C. K. Tembhurkar, and S. B. Jawalekar. 2020. "Pyrolysis System for Environment-Friendly Conversion of Plastic Waste into Fuel." In Advances in Materials Processing, Lecture Notes in Mechanical Engineering Springer, 131-38. https://doi.org/10.1007/978-981-15-4748-5_13.

86. Waghmare, Subhash, Sagar Shelare, Piyush Sirsat, Nilesh Pathare, and Shrikant Awatade. 2020. "Development of an Innovative Multi-Operational Furnace.” International Journal of Scientific and Technology Research 9 (4): 885-89.

87. Wang, B. X., and G. P. Peterson. 1994a. "Frictional Flow Characteristics of Water Flowing through Rectangular Microchannels.” Experimental Heat Transfer 7 (4): 249-64. https://doi.org/10.1080/08916159408946484.

88. Wang, Chi Chuan, Kai Shing Yang, Jhong Syuan Tsai, and Ing Youn Chen. 2011. "Characteristics of Flow Distribution in Compact Parallel Flow Heat Exchangers, Part I: Typical Inlet Header.” Applied Thermal Engineering 31 (16): 3226-34. https://doi.org/10.1016/j.applthermaleng.2011.06.004.

89. Wang, Hongtao, Zhihua Chen, and Jianguo Gao. 2016. "Influence of Geometric Parameters on Flow and Heat Transfer Performance of Micro-Channel Heat Sinks.” Applied Thermal Engineering 107: 870-79. https://doi.org/10.1016/j.applthermaleng.2016.07.039.

90. Wang, Junye. 2011. "Theory of Flow Distribution in Manifolds." Chemical Engineering Journal 168 (3): $1331-45$. https://doi.org/10.1016/j.cej.2011.02.050.

91. Wang, Junye, and Hualin Wang. 2015. "Discrete Method for Design of Flow Distribution in Manifolds.” Applied Thermal Engineering 89: 927-45. https://doi.org/10.1016/j.applthermaleng.2015.06.069.

92. Webb, Ralph L. 2003. “Effect of Manifold Design on Flow Distribution in Parallel Micro-Channels.” Advances in Electronic Packaging 2: 527-35. https://doi.org/10.1115/ipack2003-35251.

93. Wu, H. Y., and P. Cheng. 2005. “Condensation Flow Patterns in Silicon Microchannels." International Journal of Heat and Mass Transfer 48 (11): 2186-97. https://doi.org/10.1016/j.ijheatmasstransfer.2004.12.034.

94. Wu, Jiafeng, Mingheng Shi, Yongping Chen, and Xin Li. 2010. "Visualization Study of Steam Condensation in Wide 
Rectangular Silicon Microchannels." International Journal of Thermal Sciences 49 (6): 922-30. https://doi.org/10.1016/j.ijthermalsci.2010.01.007.

95. Xia, G. D., J. Jiang, J. Wang, Y. L. Zhai, and D. D. Ma. 2015. "Effects of Different Geometric Structures on Fluid Flow and Heat Transfer Performance in Microchannel Heat Sinks." International Journal of Heat and Mass Transfer 80: 439-47. https://doi.org/10.1016/j.ijheatmasstransfer.2014.08.095.

96. Yang, Dawei, Zhiyu Jin, Yan Wang, Guifu Ding, and Guilian Wang. 2017. "Heat Removal Capacity of Laminar Coolant Flow in a Micro Channel Heat Sink with Different Pin Fins.” International Journal of Heat and Mass Transfer 113: 366-72. https://doi.org/10.1016/j.ijheatmasstransfer.2017.05.106.

97. Yang, Dawei, Yan Wang, Guifu Ding, Zhiyu Jin, Junhong Zhao, and Guilian Wang. 2017. "Numerical and Experimental Analysis of Cooling Performance of Single-Phase Array Microchannel Heat Sinks with Different Pin-Fin Configurations." Applied Thermal Engineering 112: 1547-56. https://doi.org/10.1016/j.applthermaleng.2016.08.211.

98. Yiamsawas, Thaklaew, Omid Mahian, Ahmet Selim Dalkilic, Suthep Kaewnai, and Somchai Wongwises. 2013. "Experimental Studies on the Viscosity of TiO2 and Al2O3 Nanoparticles Suspended in a Mixture of Ethylene Glycol and Water for High Temperature Applications.” Applied Energy 111: 40-45. https://doi.org/10.1016/j.apenergy.2013.04.068.

99. Zeng, Dehuai, Minqiang Pan, and Yong Tang. 2012. "Qualitative Investigation on Effects of Manifold Shape on Methanol Steam Reforming for Hydrogen Production.” Renewable Energy $39 \quad$ (1): 313-22. https://doi.org/10.1016/j.renene.2011.08.027.

100. Zhang, Yanjun, Shuangfeng Wang, and Puxian Ding. 2017. "Effects of Channel Shape on the Cooling Performance of Hybrid Micro-Channel and Slot-Jet Module." International Journal of Heat and Mass Transfer 113: $295-309$. https://doi.org/10.1016/j.ijheatmasstransfer.2017.05.092.

101. Zhou, Feng, and Ivan Catton. 2011. "Numerical Evaluation of Flow and Heat Transfer in Plate-Pin Fin Heat Sinks with Various Pin Cross-Sections." Numerical Heat Transfer; Part A: Applications 60 (2): 107-28. https://doi.org/10.1080/10407782.2011.588574.

102. Zhou, Nianyong, Fujiang Chen, Yuchun Cao, Mengmeng Chen, and Yu Wang. 2017. "Experimental Investigation on the Performance of a Water Spray Cooling System." Applied Thermal Engineering 112: 1117-28. https://doi.org/10.1016/j.applthermaleng.2016.10.191. 

